\title{
Effects of Support Pantyhose with Loop Length Controlled in the Course Direction on the Swelling of Lower Legs, Fatigue and Comfort
}

\author{
NAKAHASHI Miyuki*, MOROOKA Harumi**, NAKAJIMA Chie***, \\ SATOH Seizo****, and MOROOKA Hideo***** \\ *, ***** Nara Women's University, Kitauoyahigashi-machi, Nara, 630-8506 Japan \\ ** Toyama University, 3190, Gofuku, Toyama, 930-8555 Japan \\ ***, ${ }^{* * * *}$ Asahi Chemical Industry Co., LTD. Takatsuki, Osaka, 569-0096 Japan
}

Received 14 June 2000 ; accepted for Publication 17 January 2001

\begin{abstract}
This paper aims to clarify wear performance of trial support pantyhose of which front pressure was lower by being controlled loop length in course direction. Experiments for examining effects of trial pantyhose on swelling of lower legs, fatigue (Reaction time (RT), Flicker value (FV)), compressive feeling and comfort were made. As subjects, thirty-three women working in a department store were employed.

The results obtained were as follows:

1) When the mean clothing pressure of pantyhose is higher, the swelling of lower legs ( $\mathrm{Sw}$ ) became smaller significantly. In a case of $\mathrm{Sw}>0$, the trial pantyhose were more effective than the pantyhose on the market.

2) Increase in RT of three kinds of pantyhose after work was smaller significantly than that of a pantyhose with the lowest clothing pressure in all samples used. There was no significant difference in FV.

3) Score of compressive feeling of trial pantyhose was lower than that of the pantyhose on the market.

4) Compressive comfort of the trial pantyhose knitted in single covered yarn was almost independed on the preference of the clothing pressure.
\end{abstract}

Key Words : Support pantyhose; Swelling; Fatigue; Comfort; Compressive feeling

コース方向にループ長をコントロールしたサポートパンティ

ストッキングの脚部の浮腫, 疲労度および圧快適性への効果

中橋 美幸*, 諸岡 晴美 ${ }^{* *}$, 中島 千恵 ${ }^{* * *}$, 佐藤 精三 $* * * *$, 諸岡 英雄 $* * * * *$ 


\section{1. 緒 言}

筆者らは，これまでの研究において，生理的にも心理 的にも快適な衣服圧をもつサポートパンティストッキン グ（以後，PSとする）を開発することを目的として一 連の研究を行ってきた。 その結果, サポート力の大きい PS が，下腿部の浮腫を抑制する効果をもつことが明ら かとなった[1]．しかし，脚部末梢部の皮虑血流量を大 きく減少させること [2]，また，高い衣服圧を好まない 女性にとってはかなりの心理的不快感を伴うこと[3]な ど，問題点も明らかになってきた.

一般に，サポートPSの衣服圧分布は，体幹側（大腿 部）から末梢部 (足首部)にかけて順次高くなるよう， ウェール方向にコントロールされている，しかし，前述 の問題点を解決するためにはコース方向の衣服圧分布も 検討する必要があると考え，これに関連した基礎的な研 究をこれまで行ってきた.その結果, 下腿部周径の約 $25 \%$ を非加圧にすることで，末梢部の皮膚血流量の減少を抑 制できることをモデル実験で明らかにした[4]．また， 下腿部の脛骨にあたる前面部分で，できるだけ衣服圧を 低くした膝下ストッキング（足なし）が圧感覚を低下さ せるのに有効であることを, 実験室内での実験で明らか にしてきた $[5]$.

そこで本研究では, サポートPSの衣服圧分布を ウェール方向のみならず，コース方向においてもコント ロールしたサポートPS を試作し，その有用性をフィー ルド実験により明らかにすることを目的として, 試作 PS が脚部の浮腫および度労度（全身反応時間およびフリッ カー値）に及ほす影響と圧感覚および圧快適性に及ほす 影響について検討する。

\section{2. 実験方法}

\section{1 試 料}

着用実験に用いた試料の詳細を表 1 に示す。試料はす ベてゾッキ構造（カバード糸100\%）である.PS 2 およ びPS 3 は試作 PS であり，それぞれポリウレタン糸（芯 糸) の太さが44dtex のシングルカバード糸（SCY）およ びダブルカバード糸 (DCY) からなる.これまでの研究 結果に基づいて, 下腿部前面を中心とする周径寸法の約 25\%で後面より衣服圧をできるだけ低く設計するため

Table 1 Samples

\begin{tabular}{c|ccccc}
\hline Sample & Structure & Core yarn (dtex) & Covering yarn (dtex) & Remarks \\
\hline PS1 & Zokki support & U 17 & N $17 \times 2$ & (DCY) & on the market \\
PS2 & $"$ & U 44 & N 13 & (SCY) & trial \\
PS3 & $\|$ & U 44 & N $9 \times 2$ & (DCY) & $"$ \\
PS4 & $\|$ & U 22 & N 11 22 & (DCY) & on the market \\
\hline \multicolumn{5}{|l}{ U:polyurethane, N:nylon, } \\
DCY:double covered yarn, SCY: single covered yarn \\
Zokki support is knitted only in covered yarn.
\end{tabular}

に, ウェール数400針のうち 90 針において, ステッチカ ムを通常下げ幅より $0.6 \mathrm{~mm}$ 下げることによりループ長 を大きくした.PS 2 および PS 3 の下腿前面部分のルー プ長は，ともに後面の約 1.1 倍であった。 また, PS 1 お よびPS 4 については, 市販されている平編構造のサポー トPSの中からポリウレタン糸が17dtexのできるだけ衣 服圧の低いもの (PS 1)，ポリウレタン糸が22dtexので きるだけ衣服圧の高いもの（PS 4) を選択した.

図 1 は, 試料PS の衣服圧プロフィールを示している (大腿部および下腿部については前面と後面, 他は前面 の衣服圧)。着用実験で用いた試料 PS の他に，対照試 料として, 市販 PS の中で最も衣服圧が高いと思われる ポリウレタン糸が156dtex のメッシュ編構造のサポート PS（PS 5 ）を加えている。衣服圧は，標準体型の剛体 脚型マネキン（下腿最大囲 $34.5 \mathrm{~cm}$ ）に装着したときの 值であり，測定器には衣服圧測定装置 (AMI3037-2) を 使用し, 直径 $20 \mathrm{~mm}$ のエアパック型センサーに, 厚さ約 $1 \mathrm{~mm}$ となるよう空気を約 $0.3 \mathrm{ml}$ 封入して用いた。

一般に，市販 PS は曲率半径が小さい下腿部前面で後 面より高い衣服圧を示す [6].PS 1, PS 4, PS 5 につい てもそのような傾向が認められ，衣服圧が高いものほど その傾向が大きかった[5]. これに対して, 今回試作し たPS 2 およびPS 3 の前面圧は後面圧とほほ同様かやゃ 低い. 試作 PS 3 の後面圧は市販 PS 5 とほほ同程度であ るが, PS 3 の前面圧は PS 5 より約 $1.0 \mathrm{kPa}$ 低くなってお り, PS 2 の前面圧はPS 4 とほほ同程度であるが, PS 2 の後面圧でPS 4 より約 $0.7 \mathrm{kPa}$ 高くなっていることがわ かる.PS 2 とPS 3 はステッチカムの変更条件を同一に

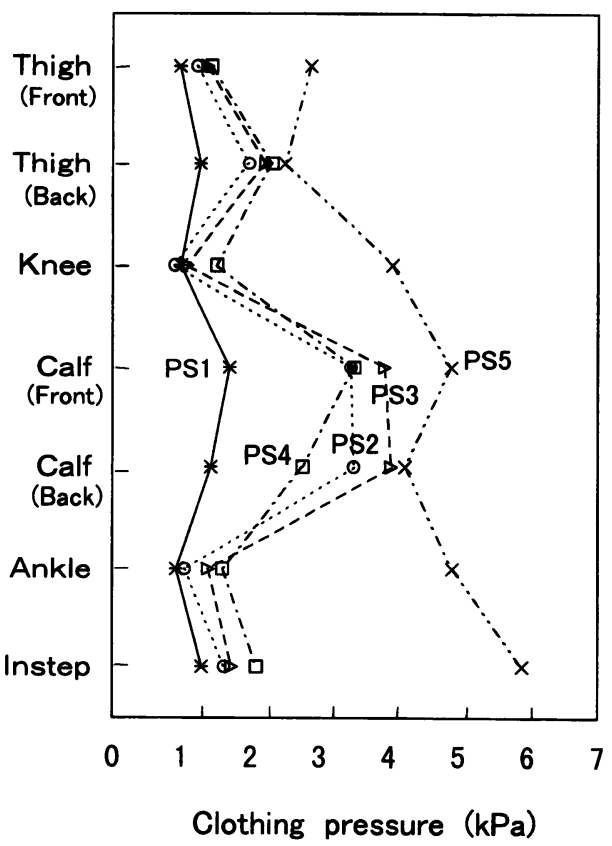

Fig. 1 Clothing pressure profile in a case of mannequin PS 2, PS 3 : Trial pantyhose

PS 1, PS 4, PS 5 : Pantyhose on the market 
して製編したものであるため，両者の衣服圧分布は類似 している。しかし, SCYからなるPS 2 より, DCYから なるPS 3 は各部の衣服圧が約 $0.3 \mathrm{kPa}$ 高くなっている. また, ウェール方向については, 試作 PS の衣服圧は44 dtex という太いポリウレタン糸を使った割に, 22dtex の PS 4 より下腿後面以外の大腿部〜膝部, 足首部一足 部でサイズ調節により衣服圧が低くなるように設計した ため, 約 $0.3 \mathrm{kPa}$ 低くなっている.

\section{2 被験者}

デパートに勤務する女性販売員を対象に，長時間立位 作業に携わり，かつ実験協力を受諾した者の中から，で きるだけ年㱓層が広がるように33名を選択した。表 $2 に$ は, 年齢, 身長, 体重, 下腿最大囲, 体脂肪率, BMI の 被験者の平均值および標準偏差を示している，年齢の範 囲は18～58歳であった。また，被験者の身体寸法を文献 值[7]と比較するため，項目の合致した身長および下腿 最大囲でみてみると, 年齢層ごとに全国平均値より +1 〜 $2 \mathrm{~cm}$ 大きかった。 そのために，身長およびヒップ囲 からなる PSの適合サイズは, M サイズ 3 名, Lサイズ 30名と, Lサイズ対応の被験者が多かった。

被験者は，適合サイズの PS を 1 日（約 9 時間） 1 足 着用することとし，計 4 日間着用実験を行った。

なお，PSの着用順序は被験者ごとにランダムとした。

\section{3 生理量の測定}

被験者は，勤務前および勤務終了後に素足になり，以 下の生理量を計測した。

\section{(1) 浮腫の計测}

脚部の浮腫の指標として, 勤務前後における下腿最大 囲の寸法増加をマルチン式テープメジャーを用いて正立 位において計測した．測定部位には油性フェルトペンで 印を入れ, 勤務前後で測定部位がずれないよう配慮した。

\section{(2) 全身反応時間の湘定}

疲労度の指標として, 被験者が赤色の光刺激を認知し てからジャンプ動作に至るまでの反応時間を測定した。 測定器には全身反応測定器 II 型 (竹井機器工業株式会社) を用い, 各被験者 $2 \sim 3$ 回練習を行った後に連続して10 回測定し，その平均值を算出した。

一般に, 疲労とは精神的, 肉体的に作業の量や能率が 低下する状態と定義されていることから [8]，全身反応
時間が遅いほど疲労度が大きいと判断される。

\section{（3）フリッカー値の測定}

同様に, 疲労度の指標として, TKK ポータブルフリッ カー (竹井機器工業(侏) を用い, 光の点滅速度を継続的 に減少させ, 被験者がそれを連続光と見えるか, 断続光 と見えるかの境界における閥値, すなわちフリッカー值 を測定した。被験者は椅座位とし，5回繰り返し測定し， その平均値を算出した。

\section{4 心理的主観評価}

被験者は，勤務終了後，PS 着用のままで大腿部およ び下腿部における圧感覚 (弱い1点〜強い10点), 圧快 適感（不快 1 点～快適10点）について, アンケート用紙 に記入した。

なお，各被験者は本実験に入る前日に 4 種の PS を試 着し，アンケート記入の方法についてオリエンテーショ ンを受けた。

\section{3. 結果と考察}

\section{1 脚部の浮腫}

図 2 は, 下腿部における浮腫 $(\mathrm{Sw})$ と PS の下腿後面 圧 $\left(\mathrm{P}_{\mathrm{B}}\right)$ および前後内外 4 か所の平均圧 $(\overline{\mathrm{P}})$ との関係 を示したものである. Sw は $\mathrm{P}_{\mathrm{B}}, \overline{\mathrm{P}}$ に大きく依存し, 衣 服圧の高いPS の順に Sw が比例的に小さくなることが わかる。しかし，詳細にみてみると，PS 4 は $\mathrm{P}_{\mathrm{B}}$ の割に Swがやや小さい. このことは, PS 2, PS 3 の下腿前面 圧が小さいのに対して, PS 4 では前面圧が後面圧より 高いためであると思われる，すなわち，脚部の浮腫の抑 制は平均圧により大きく依存しているものと考えられ る. 以下, 平均圧 $\overline{\mathrm{P}}$ でみてみる。

Sw は $\mathrm{P}$ 高い順に, PS 3 では0.7mm, PS 2 では1.1 $\mathrm{mm}, \mathrm{PS} 4$ では1.3mm, PS 1 では3.2mm であった. 統 計的検定でも, PS 1 に対して, 他の PS 着用時の浮腫は 有意に小さくなることがわかった $(\mathrm{p}<0.01)$.

次に，被験者の中には勤務後の脚部寸法が勤務前より 小さくなる場合がみられたので，このような被験者は高 い衣服圧をもつサポートPS を着用する必要のない, む しろ生理的には着用しない方が良い[1]女性であると考

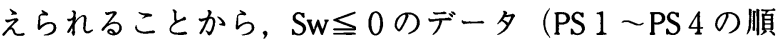
に, 5 名, 13名, 15名, 15名) を除き, Sw $>0$ のデー

Table 2 Physical characteristics of subjects

\begin{tabular}{ccccccc}
\hline $\begin{array}{c}\text { Number of } \\
\text { subjects }\end{array}$ & $\begin{array}{c}\text { Age } \\
(\text { years })\end{array}$ & $\begin{array}{c}\text { Height } \\
(\mathrm{cm})\end{array}$ & $\begin{array}{c}\text { Weight } \\
(\mathrm{kg})\end{array}$ & $\begin{array}{c}\text { Calf girth } \\
\text { circumference } \\
(\mathrm{cm})\end{array}$ & $\begin{array}{c}\text { Fat } \\
(\%)\end{array}$ & BMI $^{1)}$ \\
\hline 33 & $34.3 \pm 12.8$ & $158.2 \pm 5.0$ & $54.5 \pm 7.1$ & $35.0 \pm 2.5$ & $24.4 \pm 4.5$ & $21.8 \pm 2.7$ \\
\hline
\end{tabular}

1) Weight(kg)/Height(m) $)^{2}$ 


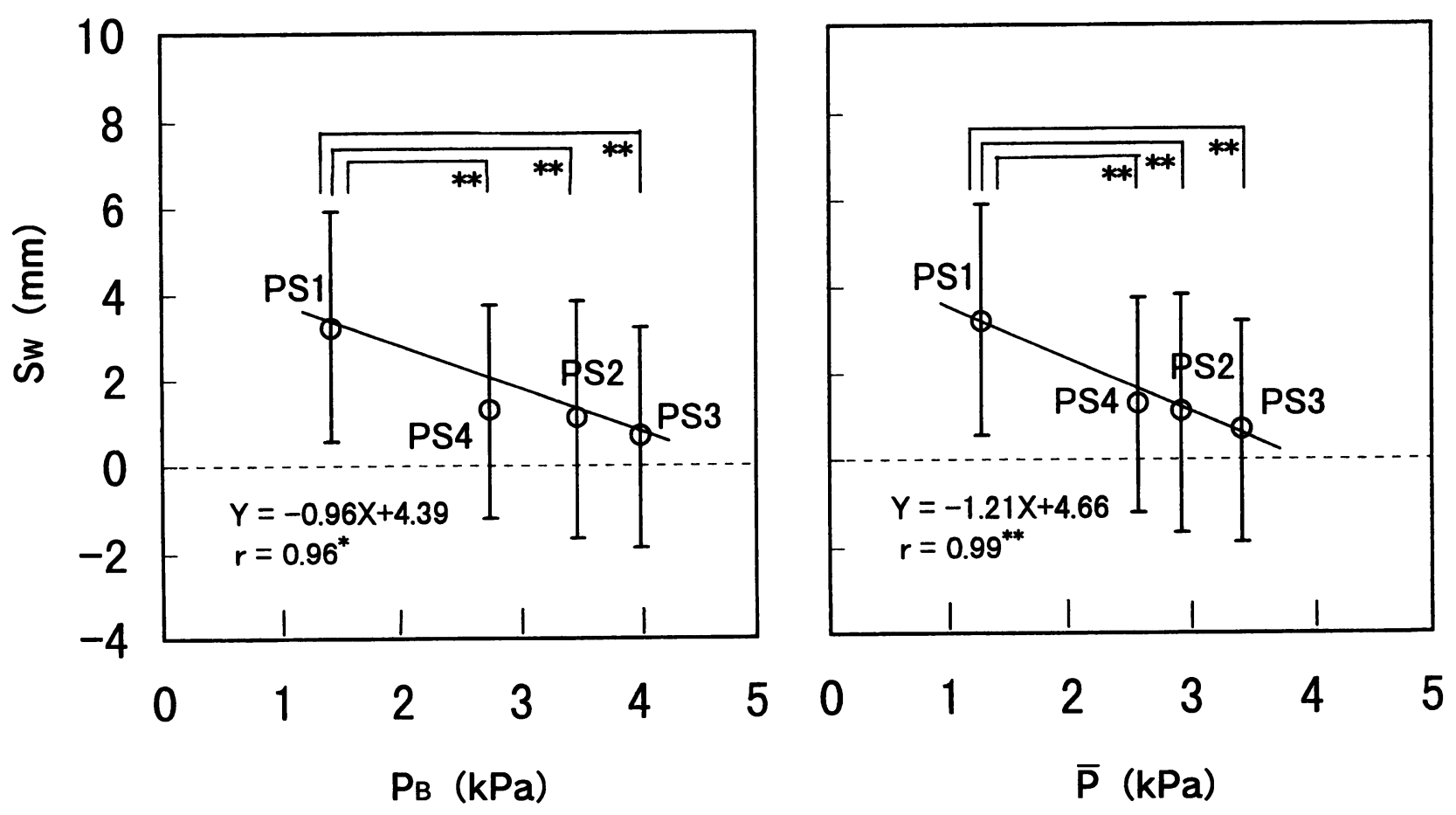

Fig. 2 Relationship between swelling on lower legs $(\mathrm{Sw})$ and clothing pressure $\left(\mathrm{P}_{\mathrm{B}}\right)$ or $(\overline{\mathrm{P}})$

夕のみを用いて，再度検討した。 その結果は先程と同様 に, Sw はPが高い順に小さく, PS 3 では $2.7 \mathrm{~mm}$, PS 2 では $2.8 \mathrm{~mm}$, PS 4 では $3.4 \mathrm{~mm}, \mathrm{PS} 1$ では $4.0 \mathrm{~mm}$ であっ た.この場合, PS 1 に対して, PS 2 およびPS 3 着用時 の浮腫減少に有意差が認められたが $(\mathrm{p}<0.01)$, PS 4 では有意でなくなった。すなわち, 試作のPS 2 , PS 3 の着用は, 市販のPS 1 , PS 4 に比べて, 脚部が浮腫や すい人にとってより効果的であると判断できる.

なお, $\mathrm{Sw}<0$ で, 勤務後に下腿部周径が小さくなっ

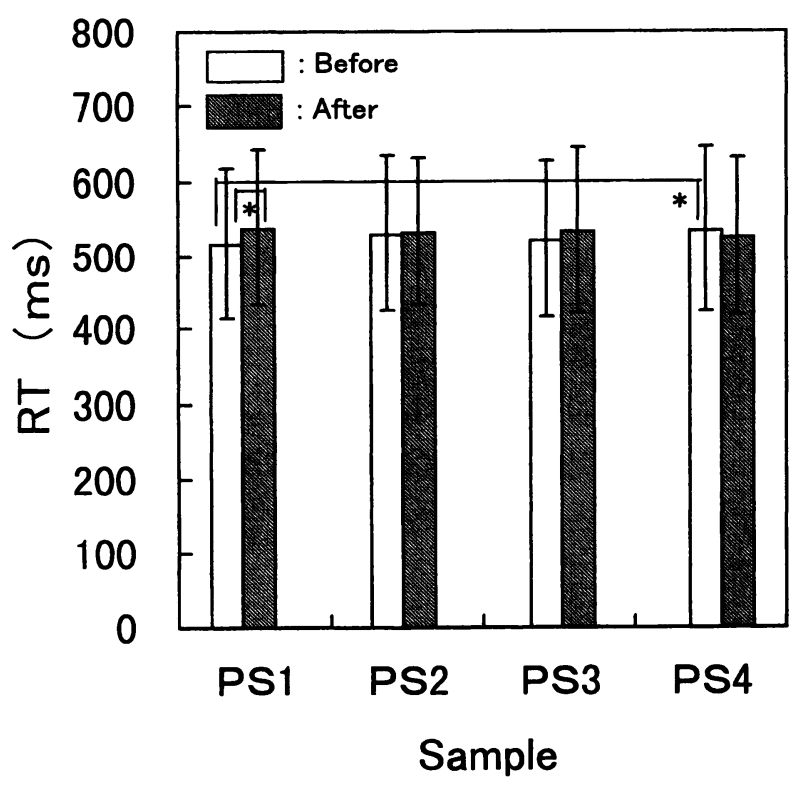

(a)
た被験者はPS 1 PS 4 の順に2 名, 8名, 10名, 8 名 であり，平均值はどの PSにおいても約 $-0.2 \mathrm{~mm}$ であっ た.すなわち, PS 2 , PS 3 は, 浮腫減少効果が大きかっ た割には，1日着用後の下腿部のつぶれ（圧縮方向の塑 性変形) の少ないPS であることがわかった[1].

\section{2 全身反応時間への影響}

図 3 (a) は，勤務前後における反応時間 RT を示し ている，被験者によりRTの值が大きく異なったため標

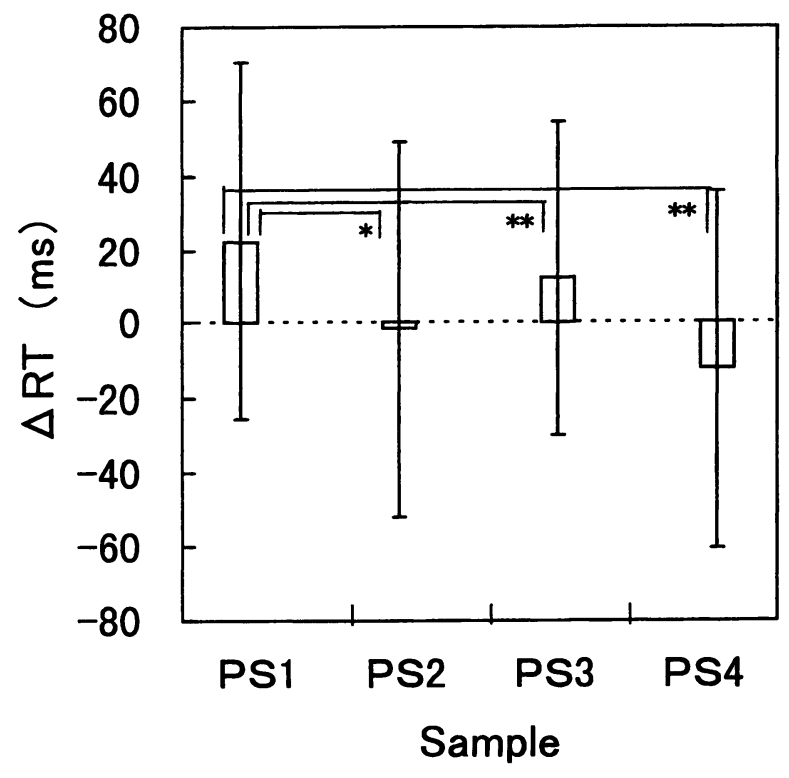

(b)

Fig. 3 Reaction time $(\mathrm{RT})$ and difference of that before and after work $(\Delta \mathrm{RT})$ 


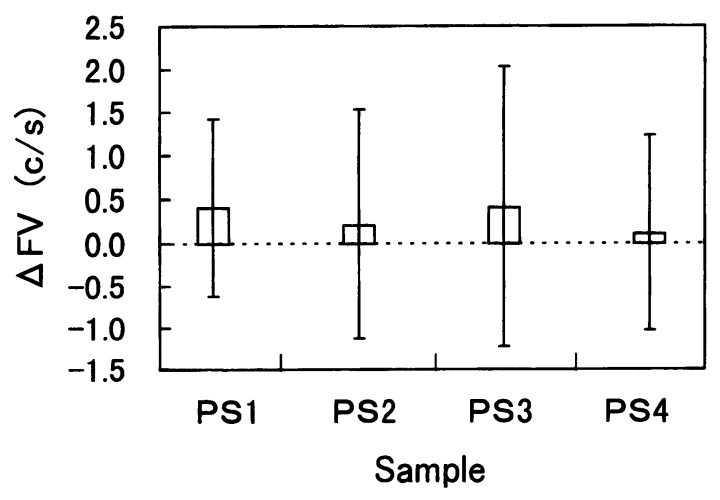

Fig. 4 Difference in flicker value before and after work $(\Delta \mathrm{FV})$

準偏差がかなり大きくなっている．まずはじめに，勤務 前後の RT を比べてみると, PS 4 を除く他の PS ゙勤務 後の RT が大きく, 反応時間が遅くなっていることがわ

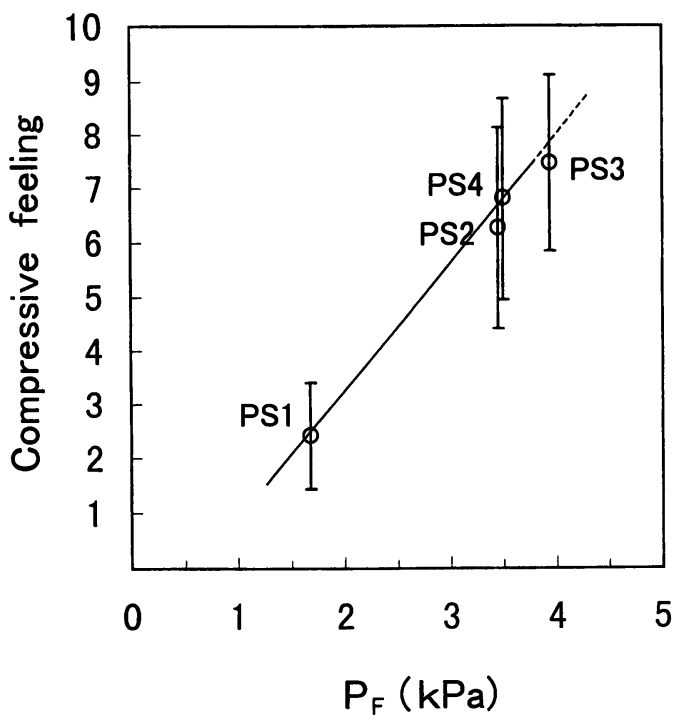

かる、特に, PS 1 では約 $20 \mathrm{~ms}$ 有意に RT が増大した（p <0.05). 一方, PS 4 では勤務前後の RT が逆転してい る. 着用順序をランダムとしたので曜日によるものとは 考えられないが, PS 1 着用日より有意に勤務前 RT が高 かった。

そこで次に，各被験者ごとに勤務前後における RT の 変化量 $\Delta R T$ （=勤務後 RT一勤務前 RT）を算出した後, 被験者平均を算出した（図 3 (b)). $\Delta \mathrm{RT}$ は PS 1 で22.4 $\mathrm{ms}$ と最も大きく，これに比べて PS 2 でー $1.6 \mathrm{~ms}(\mathrm{p}<$ $0.05)$, PS 3 で $12.3 \mathrm{~ms}(\mathrm{p}<0.01)$, PS 4 で $-12.2 \mathrm{~ms}$ (p <0.01）とPS1より有意に小さかった。すなわち, PS 2 , PS 3 およびPS 4 の着用が, 疲労度の軽減に有効で あると判断された。

\section{3 フリッカー値への影響}

フリッカー值 FVについてはかなりの個人内変動がみ

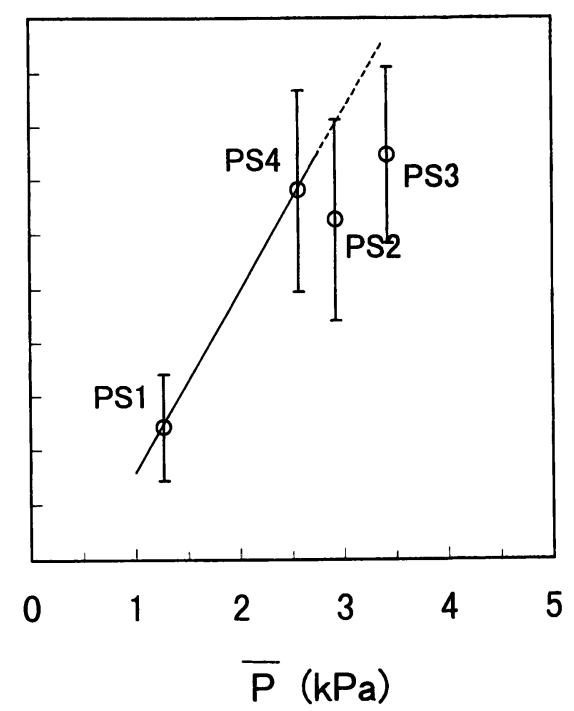

Fig. 5 Relationships between compressive feeling and clothing pressure $P_{F}$ or $\bar{P}$ on lower leg
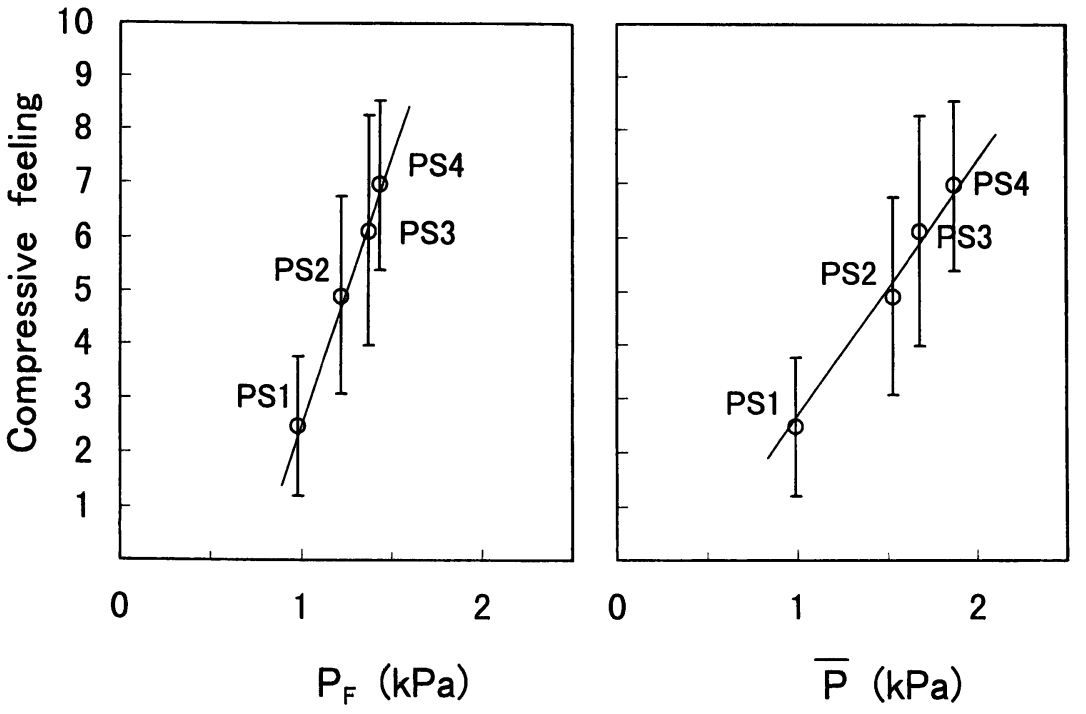

Fig. 6 Relationships between compressive feeling and clothing pressure $P_{F}$ or $\bar{P}$ on thigh 
られたそそこで，特に勤務前 $\mathrm{FV}$ のばらつきが着用日に より大きく異なった被験者 6 名を除いて, PSごとに勤 務前後の変化量 $\Delta \mathrm{FV}$ (=勤務前 $\mathrm{FV}$ 一勤務後 $\mathrm{FV}$, 疲労度 が大きいほど数值が小さくなるため)の平均值を求めた. 結果を図 4 に示す。すべてにおいて有意差はみられな かったが， $\Delta \mathrm{FV}$ はPS 1 で0.4c/s と大きく，これに対し て PS 2 では $0.2 \mathrm{c} / \mathrm{s}, \mathrm{PS} 4$ では0.1c/s と PS 1 より小さかっ た。しかしながら, PS 3 の $\Delta \mathrm{FV}$ は $0.4 \mathrm{c} / \mathrm{s}$ と PS 1 と同程 度であり，フリッカー値への効果はみられなかった。

\section{4 脚部における PS の圧感覚}

下腿部における圧感覚と, 前面圧 $P_{\mathrm{F}}$ および平均圧 $\bar{P}$ との関係を図 5 に示す。図中の直線は, PS 1 と PS 4 を 結ぶ直線であり，市販品の衣服圧と圧感覚との関係を示 すものである.PS 2, PS 3の圧感覚は，PFからみる， 図中の直線にかなり近似しているが, $\overline{\mathrm{P}}$ からみると，市 販品より約 2 点程度圧感覚が小さいことがわかった。

この結果は，女子大学生および中年齢層の女性18名を 被験者とした着用時の衣服圧を用いた場合[5]と同様の 結果であり，被験者数を拡大した今回のフィールド実験 でも圧感覚が下腿前面圧に依存することが認められた。

図 6 は，大腿部における圧感覚と $\mathrm{P}_{\mathrm{F}}, \overline{\mathrm{P}}$ との関係を示 したものである。大腿部においては，図1にみられるよ うに前後の衣服圧分布にPS $2, \mathrm{PS} 3$ とPS 4 との相違が

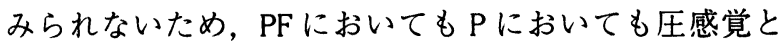
の関係に直線関係がみられた。ここで，大腿部前面と下 腿部前面の衣服圧と圧感覚との関係をみるために, 図中 の直線の傾きをみてみると, 大腿部では下腿部の約 4.7 倍と大きく，このことは，大腿部での圧感受性の大きい ことを示唆しており [9]，PS 2 PS 4 の大腿部での衣服 圧の差が小さい割に圧感覚の差が大きかった.

\section{5 脚部における圧感覚と快適感との関係}

これまでの研究において，高い衣服圧をもつPSを好 む女性とそれを好まない女性がいることがわかっている $[1,9]$.そこで 4 種の PS の中で最も衣服圧の低い PS 1 を最も快適であると評価したグループW（L）と，PS 1 以外の衣服圧の高い他の 3 種のPS のうちのいずれかに ついて最も快適であると評価したグループ W（H）に分 けて検討した．前者は高い衣服圧を好まないグループて あり，後者は好むグループであるとみなすことができる。 W（H）は27名と全体の約 $80 \% を$ 占め，デパートに勤務 する女性販売員の場合，高い圧を好む女性が圧倒的に多 いことがわかった。これに対して，W（L) は6 名と少 なかったが，衣服圧の高いPS を好まない女性もみられ た.

図 7 は，下腿部および大腿部における圧感覚と快適感 との関係について，それぞれグループ別にプロットし， 近似曲線を示したものである。また，両グループ間の感 覚の相違をみるために，両グループの評価点を PS ごと に矢印で結んでいる。不退部においては，両グループは 上に凸の 2 次曲線で表され，压感覚が W（L）では約 4 点, W (H) では約5.5点で快適感が最大となり, 圧感 覚の最も大きかったPS 3 の快適感評価は低かった。

次に，快適感における両グループ間の評価点の差は， $\mathrm{PS} 1>\mathrm{PS} 3>\mathrm{PS} 4>\mathrm{PS} 2$ の順に大きく, PS 1 および PS 3 においては有意差が認められた，PS 2, PS 4では両 グループ間の評価点の差が各々約 1 点, 約 2 点であり, PS 2 が最も被験者の衣服圧の好みに依存しないことが わかった。

大腿部においては，W（L) は右下がり，W（H）は 右上がりで，両者は圧感覚が約 5 点で交差した。すなわ
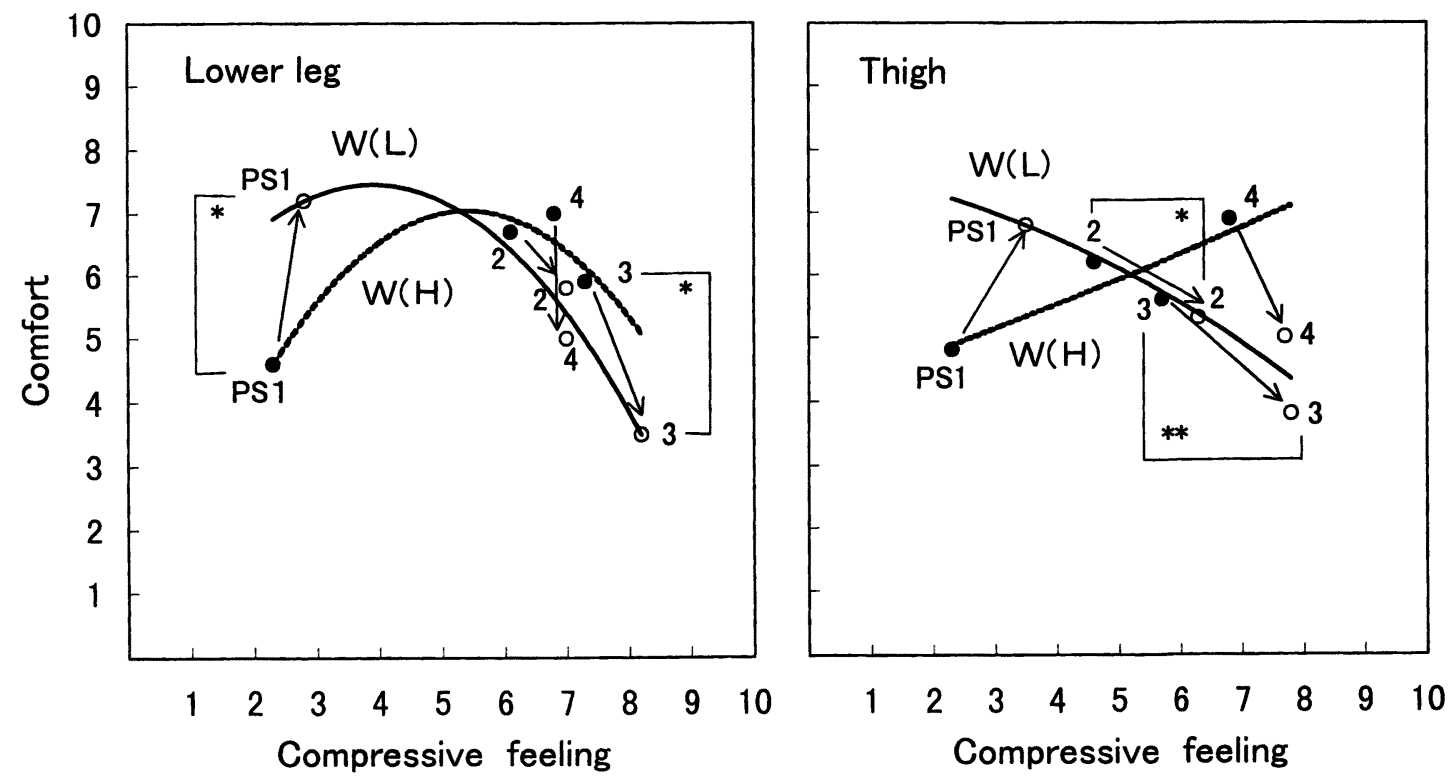

Fig. 7 Relationships between comfort and compressive feeling on lower leg or thigh 
ち, W（L）は圧感覚が小さいほど快適であると評価し, W（H）は圧感覚が大きいほど快適であると評価した。

また，快適感における両グループ間の評価点の差には 有意差はなかったが, PS 1, PS 3, PS 4 では約 2 点, PS 2 では約 1 点と最もグループ間の差が小さかった，以上 のことから PS 2 は，下腿部，大腿部ともに，被験者の 衣服圧の好みに大きく依存しないPSであることがわ かった。

一方，被験者の属性による違いをみるために，女子大 学生 10 名（年齢 $21.1 \pm 0.8$ 歳, 身長 $156.8 \pm 1.9 \mathrm{~cm}$ ）を追 加して同様の着用感評価を行なったところ，高い衣服圧 を好むグループが 6 名，それを好まないグループが 4 名 と, 両者の人数比率はデパート販売員の結果と異なり， 低い圧を好む女性が多かった。しかし，グループごとの 圧感覚と快適感との関係は先の結果とほほ同じ傾向を示 すことがわかった。

\section{6 アンケート自由記述の中からの PS3 についての問題点}

PS 3 は図 5 にみられるように，下腿部の衣服圧が今
回用いたPS の中で最も高く, 圧感覚も大きかった.ア ンケートの自由記述においても“ややきつすぎる”との 意見がみられた。また, PS 3 は着用中にパンティ部が ずり落ちて不快であったとの申告もみられた。

そこで, PS 布の引張り特性の測定を試みた。 カトー テック製の引張り・せん断測定機（KES-FB 1 ）を用い, 引張り速度を $0.2 \mathrm{~mm} / \mathrm{sec} と し$, 最大荷重 $785 \mathrm{~N} / \mathrm{m}$ まで測 定した。PS をマネキンに装着し, つかみ幅 $5 \mathrm{~cm}$, つか み間隔 $2.5 \mathrm{~cm}$ に油性ペンで印をつけ，その後脱着して 静置状態で，供試料布の寸法を長さ $7.5 \mathrm{~cm} \times$ 幅 $9.0 \mathrm{~cm}$ と して裁断した。つかみ幅 $5 \mathrm{~cm}$ になるよう厚紙で挟み接 着剂で固定した。 また, 試料をチャックにつかむ前に電 気的に0をとり, その後, つかみ間隔 $2.5 \mathrm{~cm}$ の印に合 わせてチャックに固定した.

結果を図 8 に示す．伸びひずみ 0 は正立位状態での張 力を示しており，その後の伸びは動作時の皮膚伸びに応 じて伸びた時の張力とみることができる，例えば，作業 中の膝の屈伸による皮膚の伸びは, 最大でウェール方向 に約60\%，コース方向に約40\%である [10]．全体的にみ て, PS 1 は最も伸び抵抗が小さく, PS 2 とPS 4 はほほ

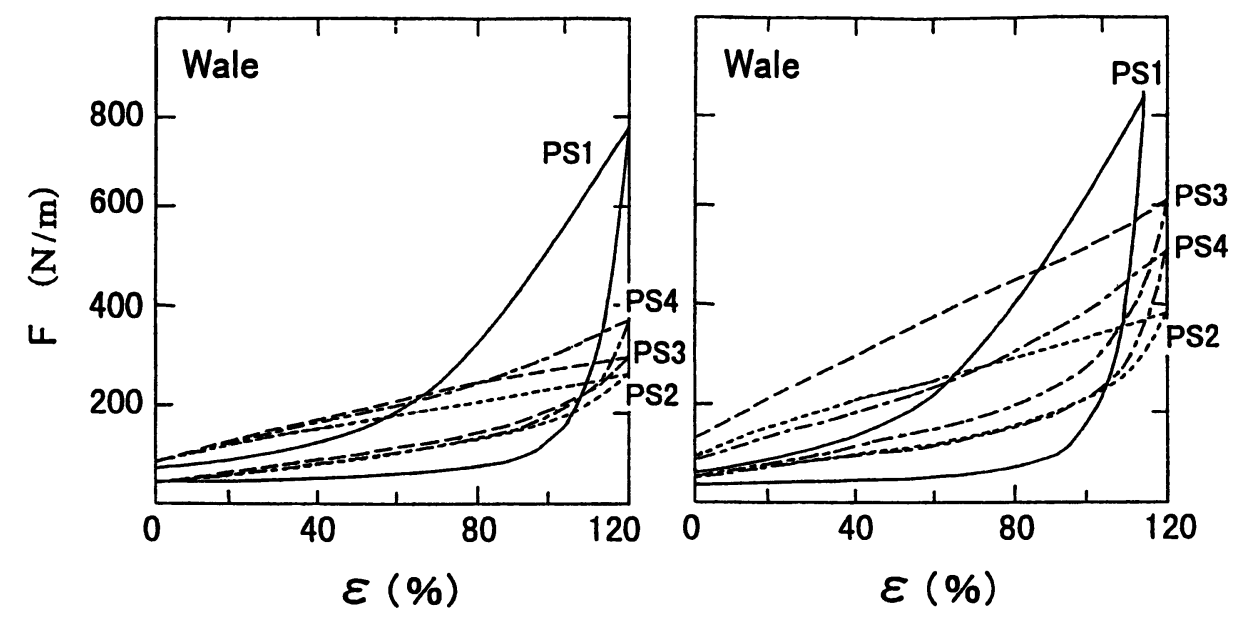

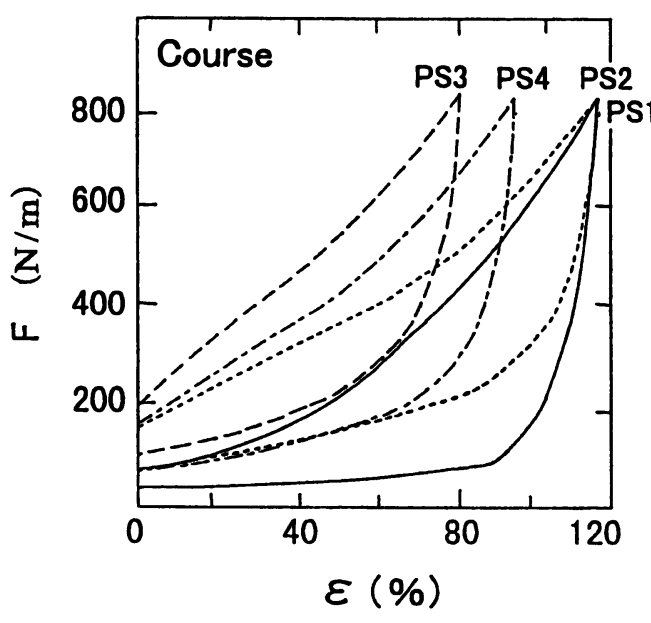

(a) Front

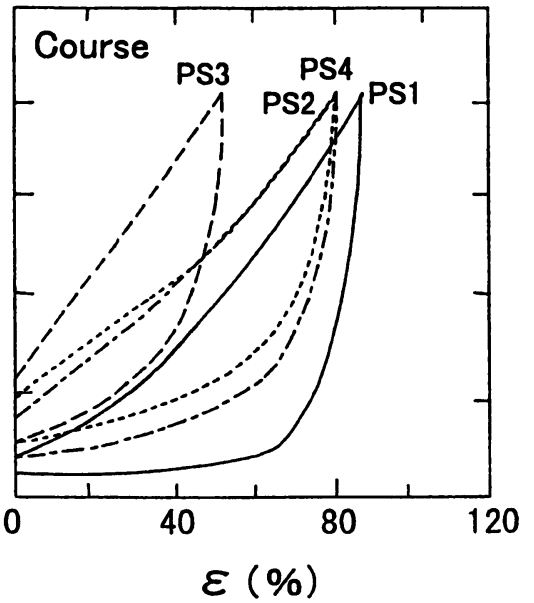

(b) Back

Fig. 8 Tensile properties of pantyhose of the front and back parts of lower leg 
同程度, PS 3 が最も伸び抵抗が大きく，伸びにくいこ とがわかる。すすなわ，PS 3 は着用動作中の伸び抵抗 が大きく、このため, パンティ部のずりが生じたものと 考えられる.PS 2, PS 3 ともにポリウレタン糸44dtex のゾッキサポートPSであったが, カバード系の構造が 異なっていた.PS2 はSCY, PS 3 はDCYであったこと から，サポート糸はSCY とするのが望ましいと思われ る.

\section{4. 結 言}

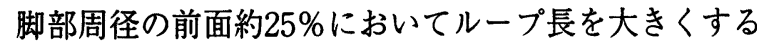
ことにより，前面圧を低く設計したサポートPS (PS 2， PS 3 ) を試作し，その着用性能を市販 PS（PS 1, PS 4) と比較検討した。試作 PS が脚部の浮腫および疲労度 (全 身反応時間, フリッカー值), 圧感覚および圧快適性に 及ほす影響を明らかにした，結果は以下の通りである。

1) 下腿部の浮腫（Sw）の度合いは, PS の下腿後面圧 に比べて平均圧 $(\overline{\mathrm{P}})$ により大きく依存し, $\overline{\mathrm{P}}$ が約 1.3 $\mathrm{kPa}$ のPS 1 に比べて, 約 $2.5 \mathrm{kPa}$ 以上の衣服圧の高 いPS 2, PS 3, PS 4 で有意に小さくなった. しか し, 浮腫の大きい被験者 $(\mathrm{Sw}>0)$ のみでみた場 合, PS 2, PS 3 のみ有意であった.

2) PS 1 と比べて, 他の 3 種のPS では, 勤務後の全身 反応時間の增加が有意に小さく, 疲労度を軽隇する と判断された。フリッカー值については, PS 2, PS $3, \mathrm{PS} 4$ ともにPS 1 との相違はみられなかった。

3 ) 前面圧の低い試作 PSにおいて, 下腿部の圧感覚が
市販 PS より小さく評価されることがわかった。

4）圧快適性については，SCY からなる試作 PS 2 が, 下腿部においても大腿部においても, 被験者の衣服 圧の好みに大きく依存しないPSであることがわ かった。しかし, DCYからなる試作PS 3 の圧快適 性は低かった，その理由として，伸び抵抗が大きい ことが挙げられた。

以上のことから，PS 2 は浮腫や疲れを抑制し，高い 衣服圧を好まない女性にとっても快適に着用できるPS であることがわかった。

\section{References}

[ 1 ] Morooka, H., Kawa, H., Morooka, H.; Jpn. Res. Assn. Text. EndUses, 36, 389 (1995)

[2] Morooka, H., Nakahashi, M., Morooka, H.; Jpn. Res. Assn. Text. End-Uses, 38, 324 (1997)

[ 3 ] Kawa, H., Morooka, H., Kitamura, K., Morooka, H.; Jpn. Res. Assn. Text. End-Uses, 36, 491 (1995)

[ 4 ] Nakahashi, M., Morooka, H., Morooka, H.; Jpn. Res. Assn. Text. End-Uses, 39, 392 (1998)

[ 5 ] Nakahashi, M., Morooka, H., Morooka, H., Hiraga, S., Deguchi, J.; Jpn. Res. Assn. Text. End-Uses, 40, 661 (1999)

[6] Itoh, N., J. Home Econ. Jpn., 44, 291 (1993)

[ 7 ] "Japanese body size data 1992-1994", Research Institute of Human Engineering for Quality Life (1997)

[ 8] Nakano, S., Shigeta, S.; "Zusetsu karada no jiten", p. 415, Asakura shoten (1992)

[9] Nakahashi, M., Morooka, H., Morooka, H.; Jpn. Res. Assn. Text. End-Uses, 41, 756 (2000)

[10] W. Kirk, S. M. Ibrahim; Text. Res. J., 36, 37 (1996) 